\title{
PREVENTIVE AND JUDICIAL LEGAL PROCEDURES FOR RESOLVING CONFLICTS IN MUNICIPAL LAW
}

\section{Lenher Ya. I.}

\section{INTRODUCTION}

The present stage of legislation development is characterized by a large number of legal acts, moreover, municipal-legal regulation is actively developing. Most often, legal conflicts arise in the process of lawmaking and law enforcement activities. They constitute contradictions between legal norms and between legal acts.

Numerous conflicts of legal acts indicate broken links, especially within the system of legislation, which points to problems of its development and efficiency of the application.

The causes of legal conflicts are laid both in the lawmaking process and in law enforcement activities. Nowadays, the reasons, which are caused by shortcomings in the application of rules, ways and methods of legal technique, predominate to a greater extent, which leads to numerous conflicts of municipal-legal acts. In turn, as practice shows, the adoption of a large number of legal acts leads to quite frequent amendments to them, which contributes to the emergence of legal contradictions.

In most cases, the proper interaction of public authorities with each other, as well as between public authorities and local self-government bodies, is complicated by emerging legal conflicts in the area of their competence delineation. First of all, a complete and detailed analysis of the causes of legal conflicts in municipal law allows correctly applying a certain method to resolve these contradictions.

General rules for resolving legal conflicts are important in resolving legal conflicts in municipal law. They presuppose that in case of contradiction of normative legal acts of different legal force, the act having the highest legal force is applied; in case of contradiction between general and special legal acts, a special legal act shall be applied; in case of contradiction between a normative legal act adopted earlier and a legal act adopted later, a normative legal act adopted later applies; laws and other legal acts should not contradict the Constitution. General rules for resolving legal conflicts in municipal law play an important role in overcoming and resolving such conflicts.

Currently, legislation requires prompt resolution of legal conflicts. Overcoming and eliminating municipal-legal conflicts is achieved through effective ways of resolving them. The ways of resolving legal conflicts in municipal law are aimed at identifying, overcoming and eliminating the latter. 


\section{Basic procedures for resolving conflicts in municipal law}

Law regulates social relations, including controversy, with the help of a special tool of social management - the mechanism of legal regulation ${ }^{1}$.

Legal regulation should be understood as the activity of the state and society in the preparation and adoption of regulatory legal acts ${ }^{2}$. In this process, the leading role belongs to the state, its legislative and executive bodies. Local self-government bodies issue regulations within their competence.

Legal regulation is performed with certain and quite specific legal and social objectives $^{3}$. The general legal goals of legal regulation are centered on creating a stable legal order in society, as well as bodies, institutes and institutions capable of providing protection and defense against violations of those rights, freedoms and legitimate interests, citizens and other persons, which are enshrined by the current rules of law. The overall social goals of legal regulation are aimed at achieving socially beneficial results, and above all at creating the necessary conditions for society's progressive development and prosperity.

Legal methods include legal norms, enforcement acts, contracts, legal facts, subjective rights, legal obligations, etc. ${ }^{4}$.

In legal science, there are different ways of eliminating and overcoming legal conflicts, which are covered by the term "resolution" of the latter. Since the difference between eliminating and overcoming collisions is rather conditional, most scholars employ only the notion "conflict resolution", therefore, this study utilizes the term "conflict resolution", which includes all ways of conflict elimination and prevention.

It includes the following elements:

1) general principles, or fundamental rules of resolving conflicts in municipal law;

2) availability of normatively fixed and detailed procedures for avoiding and resolving conflicts in municipal law;

3) a statutory measure of liability for law violation.

The legal procedure is a special, statutory procedure for the implementation of legal activity, ensuring the implementation of substantive law and substantive relationships based on them, protected from violations by legal sanctions ${ }^{5}$.

${ }^{1}$ Шундиков К. В. Правовые механизмы: основы теории. Государство и право. 2006. № 12. C. 14.

${ }^{2}$ Толстик В. А. Технико-юридические приемы выявления, устранения и преодоления формально-логических противоречий. Проблемы юридической техники. Новгород, 2000. C. 46. C. 230 .

${ }^{3}$ Скакун О. Ф. Теорія держави і права: підручник: пер. з рос. Харків: Консум, 2001.

${ }^{4}$ Матузов Н. И., Малько А. В. Теория государства и права: учебник. 2-е изд., перераб. и доп. Москва: Юристь, 2005. С. 216.

${ }^{5}$ Егорова Н. Е., Иванюк О. А., Потапенко В. С. Проблемы противоречий в законодательстве и пути их решения. Журнал российского права. 2006. № 11. С. 55. 
The procedures for the prevention and resolution of conflicts in municipal law is a statutory procedure for authorized entities' exercising the legal activity, aimed at preventing and resolving contradictions arising from the adoption of acts of local self-government bodies and their officials when resolving issues of local importance on the part of the population directly or indirectly through local government.

The above procedures are logically divided into two types, depending on the entities that perform them and their objectives. These fall into preventive (precautionary) and judicial.

Preventive legal procedures are statutory and detailed procedures for exercising the legal activity of authorized entities aimed at preventing and avoiding legal contradictions in municipal law when issuing acts of local selfgovernment bodies and their officials in the field of local self-government.

They include:

1) forms of interaction between state authorities and local selfgovernment aimed at conflict prevention (control and coordination);

2) legal appraisal of municipal-legal acts.

The basic law of our state in Article 19 of the Constitution of Ukraine stipulates that public authorities and organs of local self-government, their public servants are under an obligation to operate only on foundation, within the limits of plenary powers and in a method, that is foreseen by Constitution and laws of Ukraine ${ }^{6}$.

Article 71 of the Law "On Local Self-Government" defines the guarantees for local self-government, its bodies and officials ${ }^{7}$. The indicated guarantees stipulate that the executive authorities, their officials have no right to interfere with the legitimate activities of bodies and officials of local self-government, and also to resolve issues that the Constitution of Ukraine ${ }^{8}$ and other laws consider to be the powers of local self-government bodies and officials, except in cases the powers delegated to them by councils and in other law-stipulated cases. Article 20 of the Law stipulates that state control over the activity of bodies and officials of local self-government may be exercised only on the basis, within the powers and in the manner stipulated by the Constitution and laws of Ukraine, and should not result in the interference of state authorities or their officials in the exercise by local governments of their own powers ${ }^{9}$.

${ }^{6}$ Конституція України: станом на 1 верес. 2016 р.: відповідно офіц. тексту. Харків: Право, 2016. 82 с.

${ }^{7}$ Про місцеве самоврядування в Україні: Закон України від 21.05.1997 р. Відомості Верховної Ради України. 1997. № 28. Ст. 34. URL: http://zakon2.rada.gov.ua/laws.

${ }^{8}$ Конституція України: станом на 1 верес. 2016 р.: відповідно офіц. тексту. Харків: Право, 2016. 82 с.

${ }^{9}$ Про місцеве самоврядування в Україні: Закон України від 21.05.1997 р. Відомості Верховної Ради України. 1997. № 28. Ст. 34. URL: http://zakon2.rada.gov.ua/laws. 136 
The Constitutional Court of Ukraine has aptly commented on the ability of prosecuting authorities to challenge acts of local self-government bodies in its resolution of April 16, 2009 No. 7- рп/ 2009 in the case of Kharkiv City Council's constitutional submission regarding the official interpretation of the provisions of Part 2 of Article 19, Article 144 of the Constitution of Ukraine, Article 25, Part 14 of Article 46, Parts 1, 10 of Article 59 of the Law of Ukraine "On Local Self-Government in Ukraine". It explains that supervision over observance of human and citizen's rights and freedoms, observance of laws on these issues are entrusted to the Prosecutor's Office of Ukraine by the bodies of local self-government ${ }^{10}$.

According to Article 19 of the Law of Ukraine "On the Prosecutor's Office", the subject of supervision over the observance and application of laws is, in particular, the observance of laws on the inviolability of the person, socio-economic, political, personal rights and freedoms of citizens, protection of their honor and dignity, if the law does not provide another order of protection of these rights ${ }^{11}$. The Constitutional Court of Ukraine states that the prosecutor's right to appeal to the court of local self-government bodies' resolutions is not absolute, since the Constitution of Ukraine stipulates that its norms are directly applicable norms, and therefore, appeals to the court for the protection of constitutional rights and freedoms of man and citizen, as well as the right to appeal in court of local self-government bodies' resolutions, are guaranteed to each directly on the basis of the Constitution of Ukraine (Article 8, part 3, Article 55, part 2) ${ }^{12}$.

Preventive procedures should be considered as appropriate forms of interaction between public authorities and local governments aimed at resolving legal conflicts. In addition, the procedure of carrying out legal appraisal of a local self-government body's normative-legal act and their officials' act can be considered as a preventive procedure.

The Basic Law of Ukraine provides for forms and means of exercising the right of territorial communities to local self-government and states that the organs of local self-government within the limits of plenary powers certain by a law make decisions which are obligatory to implementation

10 Рішення Конституційного Суду України у справі за конституційним поданням Харківської міської ради щодо офіційного тлумачення положень частини другої статті 19 , статті 144 Конституції України, статті 25, частини чотирнадцятої статті 46, частин першої, десятої статті 59 Закону України «Про місцеве самоврядування в Україні» (справа про скасування актів органів місцевого самоврядування) від 16.04.2009 р. № 7-рп/2009. URL:http://zakon2.rada.gov.ua/laws/show/v007p710-09.

${ }^{11}$ Про прокуратуру: Закон України від 14.10.2014 р. № 1697-18. Відомості Верховної Ради України. 2015. № 2-3. 120 c. URL: http://zakon3.rada.gov.ua/laws/show/1697-18

12 Конституція України: станом на 1 верес. 2016 р.: відповідно офіц. тексту. Харків: Право, 2016. 82 с. 
on the proper territory (Part 1 of Article 144 and Part 1 of Article 59 of the Law of Ukraine “On Local Self-Government”) ${ }^{13}$.

In accordance with the regulations of the Executive Committee of Uzhhorod City Council, approved by the session resolution of June 8, 2016, part 2 clearly states that the preparation and submission of draft decisions to the Executive Committee of the City Council are carried out in accordance with the regulation requirements and the record keeping instructions in the city council and its executive bodies ${ }^{14}$. The preparation of the issues to be submitted to the meetings of the executive committee is carried out by the executive bodies of the city council, city communal enterprises and establishments, which is supervised by the deputies of the mayor, administrative office of the executive committee. The preparation and submission to the Executive Committee of draft decisions containing the features of a regulatory act are carried out in accordance with the procedure established by the Law of Ukraine "On the Principles of State Regulatory Policy in the Field of Economic Activity” ${ }^{15}$. The draft resolution, in addition to the rest of the issues, must contain a comprehensive assessment of the state of affairs in the relevant issue, taking into account previous resolutions, in order to avoid repetitions or contradictions ${ }^{16}$.

Draft resolutions are mandatorily agreed as follows: pricing, tariff and regulatory policy issues is agreed with the head of the department of economy and business; financial issues - with the head of financial management; issues of communal property, housing and communal services and improvement - with the head of the department of urban economy; urban planning and land resources issues - with the heads of the department of urban planning and architecture, the department of land use ${ }^{17}$.

Therefore, we can conclude that the regulations of the Executive Committee provide for the approval of draft resolutions with the relevant specialists. Regarding the proper legal appraisal of all the above acts, very little is stated in the regulation. Moreover, considering the sufficiently large number of municipal-legal conflicts in municipal-legal acts, we consider it expedient to add instructions that each draft of the relevant act, in addition to agreeing with the appropriate specialist, should still provide legal support and expert compliance not only with the established financial, economic,

${ }^{13}$ Про місцеве самоврядування в Україні: Закон України від 21.05.1997 р. Відомості Верховної Ради України. 1997. № 28. Ст. 34. URL: http://zakon2.rada.gov.ua/laws.

${ }^{14}$ Регламент Ужгородської міської ради: затв. рішенням сесії Ужгородської міської ради від 08.06.2016 p. URL: rada-uzhgorod.gov.ua.

15 Про засади державної регуляторної політики у сфері господарської діяльності: Закон України від 26.11.2016 р. Відомості Верховної Ради України. 2004. № 9. С. 79. URL: http://zakon2.rada.gov.ua/laws/show/1160-15.

${ }_{16}$ Регламент Ужгородської міської ради: затв. рішенням сесії Ужгородської міської ради від 08.06.2016 p. URL: rada-uzhgorod.gov.ua.

${ }^{17}$ Ibid. 
urban, and land indicators, but also envisage legal compliance in each case. Regulations are considered to be standard documents and these provisions should be spelled out more clearly and in detail since without proper legal support, expertise and compliance with the law and applicable sectoral laws, it is difficult to achieve an effective mechanism for preventing and resolving municipal legal conflicts. Thus, it is specified that the term of the draft decision endorsement at the Judicial Support Department should not exceed one working day, in some cases (if it is necessary to carry out a detailed legal appraisal and preparation of a legal expertise) - two working days. The above mentioned enables us to draw the following conclusion. The term of the draft legal act appraisal at a local government body is critically short and insufficient for a thorough legal analysis. In the mentioned paragraph it is noted that only in rare cases, if it is necessary to carry out a detailed legal appraisal, the term constitutes two working days. However, the list of such cases is not outlined or specified in any document. The insufficiency of the real time for legal appraisal of a municipal-legal act is often the reason for the emergence of municipal-legal conflicts. The Judicial Support Department often hires two people, one of whom is the head and the other his/her subordinate. Due to the insufficiency of time and physical resources, they are not always able to properly assess the flow of municipal acts submitted to the council session. Here again, the real cause of legal conflicts is traced.

The draft resolution is accompanied by an advisory signed by the head of the unit responsible for preparing the draft resolution. The draft resolution developer is responsible for preparing the draft resolution in accordance with the specified requirements. The Judicial Support Department carries out the inspection of the draft for its compliance with the requirements of the current legislation and regulations of the city council within two working days ${ }^{18}$. In this provision, it is possible to trace the parallel of compliance of a municipal act with a special branch law and a regulative act of the city council.

The draft resolution is scrutinized for the adequacy of the subject of the draft resolution to the powers of the city council executive committee; conformity of the draft resolution with the norms of the Constitution of Ukraine, laws of Ukraine, other acts of legislation; compliance of draft resolutions with the requirements of the norms of rule-making techniques, a system of rules and methods for the preparation of draft acts, which ensures the most complete and accurate compliance with the form of the normative provisions of their content, simplicity of presentation and accessibility ${ }^{19}$.

\footnotetext{
${ }^{18}$ Регламент Ужгородської міської ради: затв. рішенням сесії Ужгородської міської ради від 08.06.2016 p. URL: rada-uzhgorod.gov.ua.

19 Примірна інструкція 3 діловодства в міністерствах, інших центральних органах виконавчої влади, Раді міністрів Автономної Республіки Крим, місцевих органах виконавчої влади: постанова Кабінету Міністрів України від 17.10.1997 р. № 1153. Офіційний вісник України. 1997. Число 43.50 с.
} 
According to the regulations of the respective bodies of local selfgovernment, it is envisaged to perform a legal appraisal of draft resolutions of these bodies, which involves a special study of drafts for compliance with the requirements of regulatory acts with the provision of appropriate expertise. Legal examination of draft normative acts is carried out on the subject of their compliance with the Constitution and laws of Ukraine, the norms of the current international treaties of Ukraine, in particular with regard to compliance with the provisions of the Convention on the Protection of Human Rights and Fundamental Freedoms, existing normative legal acts of greater, equal or lesser legal efficacy, established principles for the construction of regulatory acts of this type, etc.

In the process of conducting an appraisal, the legal department solves only the issue of law.

According to the results of the legal appraisal, a motivated expert opinion is drawn up, which should contain the following information:

- compliance of the legal regulation subject with the competence of the relevant local self-government body;

- conformity of the draft normative legal act content to the Constitution and the laws of Ukraine ${ }^{20}$;

- compliance of the form and text of the draft legal act with the rulemaking technique;

- information on identifying corruptogenic norms and developing recommendations for their elimination;

- proposals for bringing the draft regulatory act into conformity with the Constitution and legislation of Ukraine (in case of detection of norms that do not comply with the Constitution or legislation of Ukraine) ${ }^{21}$.

The expert opinion is initialled by the legal expert and signed by the head of the legal department.

In the case of a positive conclusion, based on the results of legal appraisal of a draft regulatory act, the director of the legal department endorses it in accordance with the established procedure ${ }^{22}$.

Legal appraisal of a draft regulatory act, depending on the number of specialists involved, may be classified as one-person or group appraisals ${ }^{23}$.

\footnotetext{
${ }^{20}$ Про затвердження Методичних рекомендацій щодо проведення експертизи проектів нормативно-правових актів на наявність корупціогенних норм: наказ Міністерства юстиції України від 23.06.2010 р. № 1380/5. URL: http://zakon3.rada.gov.ua/laws/show/en/v3099323-11.

${ }^{21}$ Регламент Ужгородської міської ради: затв. рішенням сесії Ужгородської міської ради від 08.06.2016 p. URL: rada-uzhgorod.gov.ua.

22 Ibid.

${ }^{23}$ Примірна інструкція 3 діловодства в міністерствах, інших центральних органах виконавчої влади, Раді міністрів Автономної Республіки Крим, місцевих органах виконавчої влади: постанова Кабінету Міністрів України від 17.10.1997 р. № 1153. Офіційний вісник України. 1997. Число 43.50 с.
} 
In the course of conducting one-person legal appraisal, the criteria of evaluation and generalization of individual evaluations by blocks of issues are unified, however, it does not eliminate the significant possibility of subjectivism, actual errors due to the lack of third-party control in the process ${ }^{24}$.

Group legal appraisal involves the estimate of a draft legal act by a certain number of specialists. The quality of the group expert appraisal is ensured by engaging of legal specialists with various expertise and experience, who could fulfill all the tasks of the appraisal as fully as possible ${ }^{25}$. Group legal appraisal allows for a more comprehensive and objective estimate of a draft regulatory act, however, certain difficulties may arise during its conduct related to the formulation of the unanimous expert opinion ${ }^{26}$.

The need for legal appraisal is conditioned primarily by the requirements of the Basic Law of Ukraine, namely - Part 2 of Article 19 of the Constitution of Ukraine $^{27}$, envisaging that public authorities and organs of local selfgovernment, their public servants are under an obligation to operate only on foundation, within the limits of plenary powers and in a method, that is foreseen by Constitution and laws of Ukraine.

Thus, in order to enforce the rule of law in Ukraine, proclaimed by the Basic Law of Ukraine, state authorities and local self-government bodies, their officials are requested to comply with the requirements of the law, and legal appraisal of acts is a means to ensure this principle in action. In law enforcement practice, when dealing with legal conflicts, the general rules and principles of conflict resolution in legal norms and regulations are applied. Basically, they proceed from the principle of priority of one normative act over another. According to the theory of law, legal acts are in a certain hierarchy and their conformity is determined by common law principles and priorities.

Since legal conflicts are very diverse and ambiguous in their nature, there is currently no single solution or any universal way of resolving them. Thus, foreign experience may be interesting in this regard. For instance, the Basic Law of the Federal Republic of Germany contains special rules governing possible ways of avoiding legal conflicts. It is affirmed that in order to resolve inter-state disputes, the Federation accedes to agreements on international arbitration with the sole and universally binding jurisdiction.

${ }^{24}$ Муромцев П. И. Юридическая техника: некоторые аспекты содержания понятия. Проблемы юридической техники: сб. ст. / под ред. В. М. Баранова. Нижний Новгород, 2000. C. 209.

25 Лисюткин А. Б. Юридическая техника и правовые ошибки. Государство и право. 2001. № 11. С. 75.

${ }^{26}$ Лилак Д. Д. Проблеми колізій у законодавстві України (теорія і практика): дис. ... канд. юрид. наук. Київ, 2004. С. 145.

${ }^{27}$ Конституція України: станом на 1 верес. 2016 р.: відповідно офіц. тексту. Харків: Право, 2016. 82 с. 
Article 37 of the Basic Law envisages a mechanism for overcoming constitutional legitimacy violations ${ }^{28}$.

Interference proceedings and a hierarchy of legal acts are also enshrined in the constitutions of foreign countries. For instance, the Spanish Constitution guarantees the principle of a hierarchy of legal acts, their mandatory publication, no retroactive effect, the right to legal defense, legal liability for abuse of power and its representatives. Special laws are issued for delegating legislative powers as outlined in Article 9 of the 1978 Spanish Constitution ${ }^{29}$.

The correlation of legal acts is clearly and fully reflected in the Constitution of Poland. Thus, Section 3 "Sources of Law" of the above-mentioned act clearly outlines the following sources of universally binding law: the Constitution, statutes, ratified international agreements, and regulations. A ratified international agreement is regarded as part of the rule of law in the country and is directly applicable. If a ratified agreement constitutes an international organization, the rule it establishes applies directly with priority in the event of a conflict with law (Article 92 of the 1997 Constitution of Poland). The Basic Law of Poland also sets out a clear procedure for issuing by-laws (Articles 92-97) ${ }^{30}$.

\section{Legal act harmonization and monitoring as an effective and non-conventional method of resolving conflicts in municipal law}

The attention should be paid to those ways of resolving conflicts that are characteristic of municipal law. The author of the article is inclined to believe that legal conflicts are easier to prevent than to eliminate. The first and one of the most important means of preventing a municipal-legal conflict is to indicate preliminary legal appraisal of acts and their harmonization. Predicting a contradictory situation in the regulatory field is particularly useful in preventing the occurrence of legal conflict. It is facilitated by the optimization of the relationship between theory and practice, and the analysis of the regulatory act's effectiveness. In its turn, the legislation systematization makes it inspectable and allows timely conflict detection.

The total concordance of normative legal acts helps to prevent conflicts in regulations issued by local governments. It is achieved through the harmonization of legal acts. Harmonization, in this case, should be understood as a process of ensuring coordination, comparison of the scope of powers of

28 Основной Закон Федеративной Республики Германии. ФРГ. Конституция и законодательные акты: пер. с нем. / под ред. Ю. П. Урьяса. Москва: Прогресс, 1991 (наводиться за: Конституции государств Европейского Союза / под общ. ред. Л. А. Окунькова. Москва: Инфра-М-Норма, 1997. С. 181-234).

${ }^{29}$ Конституционное (государственное) право зарубежных стран: учебник / под ред. А. С. Автономова. Москва: Юриспруденция, 2001. 410 с.

${ }^{30} \mathrm{Ibid}$. 
the entities that issue them, and achievement of goals and objectives by public authorities $^{31}$. The harmonization of legal acts is one of the methods to overcome controversy. It is implemented in stages and is also subject to certain rules. Harmonization allows for a balance between regulatory legal acts, which in turn ensures the functionality and efficiency of the legal system.

The harmonization object may be separate legal acts or parts of them which are in conflict with each other. Harmonization thus allows overcoming legal contradictions and to ensure such correlation of normative legal acts which fully corresponds to the status of the bodies having adopted them and is determined by the constitutional principles of the legal system. Supporting this statement, we mean the restoration of a previously disturbed correlation of regulatory acts with each other. Harmonization may be accompanied by the cancellation of an act that is declared invalid. However, the best method is to bring the acts into conformity with the constitutional principles through harmonization. The approximation of contradictory acts leads to a decrease in the severity of their contradictions. It should be noted that the act harmonization is not always achieved through a concordance.

The severity degree of legal contradictions determines the method and the means to be taken into account in its settlement. Harmonization of acts is most needed in times of intense reform in the legal and public spheres. The harmonization of legal acts with higher and lower legal force, conformity with national and international law, etc. is of particular importance.

The resolution of municipal-legal conflicts consists of identifying them in regulatory acts and applying the most effective ways to overcome and eliminate them. The ways of identifying legal contradictions include the monitoring of regulatory acts which allows observing inconsistencies and contradictions. Yu. H. Arzamasov argues that monitoring of legal space and law enforcement practice is a system of assessing the analysis and forecast of the legislation state and dynamics and practice of its application with the purpose of revealing their compliance with the planned result of legal regulation, as well as the expectations of the participants in legislative process, executive officers, judiciary or other bodies and, ultimately, citizens ${ }^{32}$. At the stage of rulemaking activity, monitoring performs a number of functions, namely: observation, control, analysis, which allows legal conflict timely detection $^{33}$. The function of drafting law-making programs is important. If the act does not extend to the whole country, but only to its individual territory, such as a specific administrative unit, legal prognosis and experiment are

${ }^{31}$ Илькина Н. А. Качество закона и юридическая техника. Юридическая конфликтология: материалы науч.-практ. конф. (г. Москва, 26 нояб. 2007 г.) / отв. ред. В. Н. Кудрявцев. Москва, 1995. 351 с.

${ }_{2}$ Арзамасов Ю. Г. Понятие и функции мониторинга нормативных актов. Государственная власть и местное самоуправление. 2007. № 10. С. 36.

${ }^{33}$ Ibid. C. 37. 
important. As Yu. G. Arzamasov points out, a legal experiment is an experiment where a legal act functions as a researched factor. It verifies the effectiveness of an existing act or predicts the effect of a legislative innovation $^{34}$. Monitoring of legal acts includes observation, collection, study, analysis of those legal acts related to the subject of regulation, and analysis of other analytical, statistical, official materials, public opinion research on the state of the legislation, forecasting the effect of certain normative acts.

Thus, it is a systematic volume of the necessary legal information on the development, operation and abolition of regulatory acts.

An important role in the detection of legal conflicts in the law enforcement activities is played by the analysis of legal acts, which, in turn, implies the duty of state bodies and other structures to constantly collect and evaluate information on emerging conflicts between legal acts.

In our opinion, the expedient methods for identifying municipal-legal conflicts include a register of legal acts, which allows identifying contradictions between legal acts, and thus to promote their resolution. The Ministry of Justice of Ukraine has created a Unified State Register of Regulatory Acts, which allows monitoring already existing and newly adopted legal acts ${ }^{35}$. However, the register does not appear to be fully applicable for the detection of conflicts in municipal law, since the latter often arise in disputes between different legal acts. Municipal law is characterized by by-laws, which are issued by the respective bodies of local self-government, and, accordingly, they are not subject to the provisions of the Unified State Register of Legal Acts.

In accordance with the Resolution of the Cabinet of Ministers of Ukraine of April 23, 2011 № 376 "On the Unified State Register of regulatory legal acts" and the procedure of maintaining the Unified State Register of regulatory legal acts and its usage, it is clearly established that the Register includes only regulatory acts of public authorities, acts of local selfgovernment bodies as subordinate legislation, i.e. those of a regulatory nature and are not included in the Register. However, it should be noted that each council as a local self-government body has its own register of acts. It is worth noting the progressive side of this issue since most councils now have their own electronic sites where the ordinary user can freely access any act of the local government. Unfortunately, such registers are not interconnected, therefore, using them enables interested parties to seek conflicts only on their own, when appealing to the court or resolving a respective case.

The methods of overcoming conflicts in municipal law include conflictsof-law rule establishing the procedure for applying legal acts and norms in

${ }^{34}$ Арзамасов Ю. Г. Понятие и функции мониторинга нормативных актов. Государственная власть и местное самоуправление. 2007. № 10. С. 37.

35 Про Єдиний державний реєстр нормативних актів: Указ Президента України від 27.06.1996 р. № 468. Урядовий кур’єр. 1996. № 122-123. 
case of their non-compliance; conciliation and settlement arrangements; temporary or special modes; the appeal of the relevant act in the administrative court, etc.

Legal conflicts in municipal law are very different in nature, they are ambiguous and variable. It means that a single form of conflict resolution or a certain universal solution does not exist.

As it has been noted earlier, the necessary and most commonly employed methods of preventing collisions include the activities of the entities adopting the appropriate code of conduct within the law or the competence conferred; preliminary expert appraisal of normative legal acts and determination of directions of their harmonization; systematization of legislation in order to identify conflicting rules; inventory of subordinate legislation and its accurate accounting; a clear definition of the entities' powers applying the rules of law; regulatory definition of the status of official interpretative acts and their hierarchy; regulatory consolidation of various legal procedures; determining the most optimal methods for correlating different provisions of law.

The quality of regulatory acts submitted for state registration to the justice departments is low. State registration may include acts which are not in agreement with the interested authorities, issued with competence excess of the entities of norm-making or with current legislation violation, in particular, freedoms and legitimate interests of citizens, enterprises, institutions and organizations are violated or restricted by law, or their responsibilities are not provided for by law.

Local executive authorities do not take measures to bring their legal acts into conformity with the current legislation. State registration of normative legal acts is one of the means of ensuring their legality and protection of human rights.

\section{CONCLUSIONS}

It should be emphasized that any resolution to legal conflicts, even the most serious ones, must be legal. Contradictions in municipal law must be resolved by the legal civilized method, otherwise, the conflict problem will remain.

In our view, all ways of resolving legal conflicts enshrined in domestic law interact with each other. Herewith, each of them performs its functions. The connection between the separate methods of resolving legal conflicts in municipal law can be clearly ascertained on the example of resolving legal conflicts in regulatory acts. Thus, in the process of resolving conflicts between the Constitution and other normative acts in the judicial process, the court will decide the conflict, but may at the same time apply for the interpretation to the Constitutional Court. In this way, there are ways in which collisions can be eliminated and settled. 
In order to resolve legal conflicts, it is necessary to actively and comprehensively apply methods of preventing, detecting, overcoming and eliminating them. Thus, analyzing the existing methods aimed at preventing and resolving (detecting, overcoming, eliminating) legal conflicts in the municipal law, we can conclude that their resolution requires the active and complex application of these methods (especially rulemaking and judicial procedures).

Currently, legislation requires prompt resolution of legal conflicts. Overcoming and eliminating municipal-legal conflicts is achieved through effective methods of resolving them. The ways of resolving legal conflicts in municipal law are aimed at identifying, overcoming and eliminating the latter.

Monitoring as a way of identifying legal conflicts in the lawmaking process and law enforcement activities is of special importance. Such monitoring functions as observation, collection, study, analysis of legal acts, devising plans and programs of normative draft activity, legal forecasts allow to timely identify contradictions (inconsistencies) between legal acts and to apply the most effective methods of their resolution.

Finally, it should be noted that close attention should be devoted to the prevention of legal conflicts in municipal law. Prevention is aimed at preventing legal conflicts and, in our opinion, includes: conducting a preliminary legal expert appraisal of normative legal acts and their harmonization; drafting plans and programs for bills, legal forecasts, etc.

Effective ways of resolving all possible legal conflicts in public law ensure their prompt elimination. The latter consists in the existence of conflict-of-law rules establishing the procedure for the application of legal acts and rules in case of their non-compliance; conciliation procedures; temporary or special modes; appeal against regulations in courts of general and special jurisdiction.

\section{SUMMARY}

The article is devoted to clarifying the issue of preventive and judicial procedures for resolving conflicts in municipal law. Depending on the subject of the action, the study distinguishes two main types of legal procedures used in the resolution of municipal-legal conflicts. Comparing with preventive procedures, judicial procedures are proved to be the most commonly used, however, given their complexity, judicial procedures are not always highly effective. Therefore, it is suggested to focus more on preventative legal procedures, since they are the most effective as evidenced by municipal practice. They include the expert appraisal of a legal act, their monitoring and harmonization, which allow to overcome legal contradictions and to ensure the correlation of legal acts which fully corresponds to the status of the bodies adopting them and is defined by the constitutional principles of the legal system. 


\section{REFERENCES}

1. Шундиков К. В. Правовые механизмы: основы теории. Государство и право. 2006. № 12. 214 с.

2. Толстик В. А. Технико-юридические приемы выявления, устранения и преодоления формально-логических противоречий. Проблемы юридической техники. Новгород, 2000. 406 с.

3. Скакун О. Ф. Теорія держави і права: підручник: пер. 3 рос. Харків: Консум, 2001. 430 с.

4. Матузов Н. И., Малько А. В. Теория государства и права: учебник. 2-е изд., перераб. и доп. Москва: Юристь, 2005. 316 с.

5. Егорова Н. Е., Иванюк О. А., Потапенко В. С. Проблемы противоречий в законодательстве и пути их решения. Журнал российского права. 2006. № 11. С. 54-70.

6. Конституція України: станом на 1 верес. 2016 р.: відповідно офіц. тексту. Харків: Право, 2016. 82 с.

7. Про місцеве самоврядування в Україні: Закон України від 21.05.1997 р. Відомості Верховної Ради України. 1997. № 28. Ст. 34. URL: http://zakon2.rada.gov.ua/laws.

8. Рішення Конституційного Суду України у справі за конституційним поданням Харківської міської ради щодо офіційного тлумачення положень частини другої статті 19, статті 144 Конституції України, статті 25 , частини чотирнадцятої статті 46 , частин першої, десятої статті 59 Закону України «Про місцеве самоврядування в Україні» (справа про скасування актів органів місцевого самоврядування) від 16.04 .2009 p. № 7-pп/2009. URL:http://zakon2.rada.gov.ua/laws/show/v007p710-09.

9. Про прокуратуру: Закон України від 14.10.2014 р. № 1697-18. Відомості Верховної Ради України. 2015. № 2-3. 120 с. URL: http://zakon3.rada.gov.ua/laws/show/1697-18.

10. Регламент Ужгородської міської ради: затв. рішенням сесії Ужгородської міської ради від 08.06.2016 p. URL: rada-uzhgorod.gov.ua.

11. Про засади державної регуляторної політики у сфері господарської діяльності: Закон України від 26.11.2016 р. Відомості Верховної Ради України. 2004. № 9. С. 79. URL: http://zakon2.rada.gov.ua/laws/ show/1160-15.

12. Примірна інструкція 3 діловодства в міністерствах, інших центральних органах виконавчої влади, Раді міністрів Автономної Республіки Крим, місцевих органах виконавчої влади: постанова Кабінету Міністрів України від 17.10.1997 р. № 1153. Офіційний вісник України. 1997. Число 43. 50 с.

13. Про затвердження Методичних рекомендацій щодо проведення експертизи проектів нормативно-правових актів на наявність корупціогенних норм: наказ Міністерства юстиції України від 23.06.2010 p. № 1380/5. URL: http://zakon3.rada.gov.ua/laws/show/ en/v3099323-11. 
14. Муромцев П. И. Юридическая техника: некоторые аспекты содержания понятия. Проблемы юридической техники: сб. ст. / под ред. В. М. Баранова. Нижний Новгород, 2000. 309 с.

15. Лисюткин А. Б. Юридическая техника и правовые ошибки. Государство и право. 2001. № 11. С. 72-89.

16. Лилак Д. Д. Проблеми колізій у законодавстві України (теорія і практика): дис. ... канд. юрид. наук. Київ, 2004. 245 с.

17. Основной Закон Федеративной Республики Германии. ФРГ. Конституция и законодательные акты: пер. с нем. / под ред. Ю. П. Урьяса. Москва: Прогресс, 1991 (наводиться за: Конституции государств Европейского Союза / под общ. ред. Л. А. Окунькова. Москва: ИнфраМ-Норма, 1997. С. 181-234).

18. Конституционное (государственное) право зарубежных стран: учебник / под ред. А. С. Автономова. Москва: Юриспруденция, 2001. $410 \mathrm{c}$.

19. Илькина Н. А. Качество закона и юридическая техника. Юридическая конфликтология: материалы науч.-практ. конф. (г. Москва, 26 нояб. 2007 г.) / отв. ред. В. Н. Кудрявцев. Москва, 1995. 351 с.

20. Арзамасов Ю. Г. Понятие и функции мониторинга нормативных актов. Государственная власть и местное самоуправление. 2007. № 10. C. 30-46.

21. Про Єдиний державний реєстр нормативних актів: Указ Президента України від 27.06.1996 р. № 468. Урядовий кур’єр. 1996. № 122-123.

\section{Information about the author:}

Lenher Ya. I.,

Doctor of Laws, Professor, Head of the Department of Law, Faculty of Finance, Accounting, Linguistics and Law, Lutsk National Technical University 75, Lvivska str., Lutsk, 43018, Ukraine 